\title{
RECONCEPTUALIZATION OF THE INDEMNIFICATION FOR STATE FINANCIAL LOSS BY CORRUPTORS ON THE BASIS OF PROPORTIONALITY, EFFECTIVENESS, EFFICIENCY, AND FUTURE REACH
}

\author{
SUJANA DONANDI S \\ Lecturer of Law Study of President University \\ sujana@president.ac.id
}

\section{ARTICLE INFORMATION}

\section{Article history:}

Received July 22, 2016

Revised Dec 05, 2016

Accepted May 16, 2017

\section{JEL Classifications}

D73; N35; N45

\section{Key Words:}

Re-conceptualization;

Indemnification for state financial loss;

Corruptor.

\section{DOI:}

10.21532/apfj.001.17.02.01.01

\begin{abstract}
In Indonesia, the concept of indemnification for state loss by corruptor has not met the elements of proportionality, effectiveness, efficiency, and future reach. Therefore, reconceptualization of indemnification for state loss by corruptor is necessary to confront the cunning corruptor in hiding the proceeds of corruption. The re-conceptualization can be constructed by determining remedy sanction for every legal subject sentenced guilty to corruption. The remedy sanction should not only consider the amount of money corrupted, but also the time value of the money, the budget spent to handle the case, and the potential profits obtained when the money is used well as it should be. By this sanction, the amount of money determined as remedy sanction would be proportional and would not only cover as maximum as property acquired for the result of corruption as regulated by the current regulation. In addition, by this sanction, a civil lawsuit for the properties considered as the result of corruption that could spend much money and time would be no longer necessary. Someone convicted on corruption suppose to be automatically considered did default to his promise to the state. The default could be based on his failure in acting according to his official duty or based on an agreement in business relation between the legal subject and state. Should the corruptor couldn't pay the remedy of state loss in full or partly, the remedy should not be replaced by prison sentence, but the remedy or the difference money should be reckoned as a debt to the state loss. Thus, the debt would be attached to the corruptor and would be a lifetime responsibility for the corruptor as long as he could not pay the debt to the state. The debt even would be continued by the heirs if the corruptor were pass away. Furthermore, this concept could reach the possibility that the wealth resulted of corruption would be used in the future because under these provisions, the future wealth gained
\end{abstract}

Volume 2, No. $1^{\text {st }}$ Edition (January-June 2017) 
by the corruptor could be executed as a part of the extinguishment of debt without considering whether the wealth were the result of corruption or not.

Key words:

\section{A. INTRODUCTION}

Nowadays, corruption in Indonesia is quite alarming. Assessment result of the Transparency International on Bribe Payers Index (BPI) $)^{1}$, as cited by Adi Toegarisman, shows an embarrassing fact. In 2011, BPI, based on the result of a survey of 3,000 businessmen who conducted international business in 28 countries, put Indonesia in the rank of 25 out of 28 countries, with the BPI of 7.1 out of average 7.8. ${ }_{-}^{2}$ In addition, corruption has also caused a lot of financial losses for the state. Report from the Indonesian Corruption Watch (ICW) in 2015 showed that the total state financial losses due to the corruption throughout 2015 were IDR 3.1 Trillion.

The indemnification for state financial loss in consequence of corruption is essential considering that the state financial loss has hampered the development of the country. Efforts of indemnification for state financial loss in consequence of corruption have been framed in the regulation of legislation in Indonesia by implementing additional criminal restitution

1 BPI sebagaimana dijelaskan oleh Adi Toegarisman adalah indeks yang menggambarkan praktikpraktik penyuapan yang dilakukan oleh dunia usaha terhadap para penyelenggara negara atau pejabat public di suatu negara. (M. Adi Toegarisman, 2016, Pemberantasan Korupsi Dalam Paradigma Efisiensi, Jakarta: Kompas, hlm. 2)

2 M. Adi Toegarisman, 2016, Pemberantasan Korupsi Dalam Paradigma Efisiensi, Jakarta: Kompas, hlm. 2-3. for the convicted of corruption (Article 18 Paragraph (1) letter b. Act No. 31 of 1999 Jo Act No. 20 of 2001 on Corruption Eradication hereinafter in this paper is called the Law of Corruption. In addition, the state also can file a civil suit for the properties suspected to be proceeds of corruption even if the convicted person has already died (Article 32 and 33 of the Law of Corruption).

The existing concept of indemnification for state finances is still considered less sufficient, proportionate, effective, efficient, and futuristic. The indemnification for state finances related to the case of corruption and the civil lawsuit against property suspected to be the proceeds of corruption still cannot be said proportional to return the state financial losses. The determination of indemnification has currently not been proportionate because the time value of money ${ }^{3}$ continues to decline over time. Therefore, the value of the money embezzled would degrade in the present time, in addition to the potential benefits gained if the money embezzled were used well, either for the building of infrastructure, investment, or the development of the public sector. If the proceeds of corruption were used well as it should be, the money would potentially increase the state's finances and could be increased more and more. This causes the value of the indemnification for state finances becomes irrelevant.

3 Time value of money is an economic concept which states that the value of money will change in line with the change of time. The value of money at present is bigger than the value of money in the future at the same nominal. 
The requirement to file a civil lawsuit over the proceeds of corruption will also consume time and high cost. The argumentation in lawsuit settlement is also not an easy matter considering that the corruptors are increasingly sophisticated and clever in concealing the proceeds of corruption. As a result, even if a person has been convicted of corruption, as long as it can be proven that his property is the proceed of corruption, the property cannot be used as part of the responsibility for the act of corruption he has committed.

Based on the above conditions, the authors are interested in studying a new concept or a reconceptualization of mechanism which is more proportionate, effective, efficient, and futuristic in returning the state financial losses due to corruption. The author would also like to find out a solution to the deadlock of the efforts to recover the state financial losses that has not shown a significant result yet.

\section{B. RESEARCH QUESTION}

The problem to be examined in this paper is: How is the re-conceptualization of the indemnification for the state financial loss by corruptors on the basis of proportionality, effectiveness, efficiency, and future reach?

\section{RESEARCH OBJECTIVE}

The objective of this study is to describe the re-conceptualization of the indemnification for state financial loss by corruptors on the basis of proportionality, effectiveness, efficiency, and future reach.

\section{DISCUSSION}

\section{The Weakness of Current Concept of Indemnification for State Financial Loss by Corruptors}

A corruptor must be responsible for his deeds. The penalty imposed should include imprisonment and fines. The penalty, such as fine, is not part of the corruptor's responsibility to restore the state losses, but for his deeds. The responsibility for the deeds can be concluded by the provisions of fines, as provided in Article 2 to 13 of Corruption Law.

In addition to imposing criminal penalty, the corruptor is also obliged to return the state financial losses. This is because, in principle, corruption always has implications for the emergence of state losses economically. Therefore, a corruptor is obliged to return the public money that has been taken against the law for the benefit of himself, others, or a corporation. In order to return the state financial losses, the form of punishment imposed to the convicted of corruption can be seen from the provisions of additional penalty under Article 18 of Corruption Law, as follows:

(1) In addition to additional penalty referred to in the Draft of Criminal Law, the additional penalty includes:

a. Confiscation of movable tangible or intangible goods or immovable goods which are used to or derived from the crime of corruption, including the convict's corporation where corruption is committed, and the prices of goods that replace the goods; 
b. Compensation as much as the amount of the value of property derived from crime of corruption;

c. Closure of business or part of business for a period of one (1) year at the latest;

d. Revocation of all or part of certain rights or deletion of part of particular benefits which have been or may be granted by the government to the convict;

(2) If the convict does not pay compensation as referred to in paragraph (1) letter $b$ at the latest within one (1) month after the court ruling which has permanent legal power, then his property may be seized by the prosecutor and auctioned to compensate the loss of money;

(3) In the event that the convict does not have enough wealth to pay compensation as referred to in paragraph (1) letter $b$, then he shall be punished with imprisonment with the length that does not exceed the maximum principal punishment in accordance with the provisions of this law, and therefore the punishment has been determined in the court judgment.

The author finds that the provision of additional punishment above is still less proportionate. With the provision that the compensation is as much as the amount derived from corruption, the state only calculates the compensation based on the value of the money corrupted. In fact, the handling of corruption case consumes time and high cost. Difficult burden of proof causes the law enforcement agencies to conduct in-depth investigations and examinations. Law enforcement officers often have to deal with foreign parties and go abroad to get strong evidence which, of course, requires high cost.

Based on information from hukumonline, the breakdown of costs allocated for each of law enforcement agencies is not the same from one agency to another. In Prosecutor's Office, for example, the total cost of the completion of one case of corruption is IDR 200 million. The detail is IDR 25 million for the inquiry phase; IDR 50 million for investigation phase; IDR 100 million for prosecution phase, and the rest, IDR 25 million, goes for the execution of the verdict. In Police Office, the costs of investigations and inquiries of corruption cases are also not much different, totaling IDR 208 million per case. ${ }^{4}$

In Corruption Eradication Commission Office (KPK), the system used is a ceiling system. The budget ceiling for inquiry phase is IDR 11 billion for the projection of 90 cases. The budget ceiling for investigation phase is IDR 12 billion for the projection of 85 cases. Meanwhile, the budget ceiling allocated for prosecution and execution phase is IDR 14.329 billion for 85 cases. In addition, there are still other costs that are used for execution of the entity by IDR 45 billion. $^{5}$

Based on the above data, it appears that disclosing the truth of corruption-related cases requires high cost. However, even after taking into account the cost for handling the case, the

4 http://www.hukumonline.com/berita/baca/ 1t5733f0ea01aea/mau-tahu-biaya-penangananperkara-korupsi-simak-angka-dan-masalahnya, Accessed on Wednesday, July 6,2016, at 14.20

5 ibid 
compensation is still not comparable with the potential benefits and the increased welfare of the people that may be generated when the corrupted money is used properly.

Furthermore, we can see another weakness in the provision of Paragraph (2) that is not effective, efficient, and futuristic. If a person cannot meet additional criminal restitution, then according to the provisions, his property will be confiscated as part of the liability for compensation to be paid. This provision cannot reach hidden assets belonging to the convict derived from the act of corruption. The opportunity for the convicted of corruption to embezzle assets obtained through corruption is very huge, considering that corruption is a form of fraud. To cover his fraudulent act, he is likely to commit other fraud.

If the assets of the convicted of corruption have been seized, legally, it can be said that he has run the additional penalty inflicted upon him. The problem is: how if later it is found other assets derived from the corruption? The convict has fulfilled his obligations on additional criminal restitution to the confiscation of property owned, so what will be used by the state to seize the assets derived from the act of corruption which are discovered after the criminal responsibility of the convicted of corruption has been fulfilled? In this case we can determine that the government has no basis to seize such assets.

Paragraph (3) can also be used as a loophole for corruptors who have embezzled property derived from corruption. By allowing for replacement money to be replaced with criminal penalties, the corruptor can enjoy the proceeds of corruption he has concealed after he finishes his sentence. Just as the provisions of Paragraph (2), the state has no basis to immediately seize the properties derived from the act of corruption which are discovered only after the convicted person serves his sentence.

Another weakness in the efforts to recover the state financial losses is that the state is obliged to file a civil lawsuit on the property suspected as the proceeds of corruption. The civil lawsuit can be filed both in the process of handling cases (Articles 32 and 33 of Law of Corruption) and after court ruling (Article 38). The entire provisions require that there must be found elements of state loss or property which is suspected to be the proceeds of corruption before filing a civil lawsuit. To prove these elements is not easy. In proving the existence of state losses and finding the properties suspected to be the proceeds of corruption takes a long time and it is possible that the property is known a few years after the perpetrator of corruption is defined as a convict. As stated by Adi Toegarisman, the civil lawsuit that is separated from the case investigation will ultimately lead only to the increased burden of the state's losses due to the time and cost burden for civil settlement process. ${ }^{6}$

Based on the explanation above, the author can say that the current concept of the indemnification of state finance due to corruption in Indonesia is still unable to restore the country's financial losses proportionately, effectively, efficiently, and futuristically. The

\footnotetext{
6 Adi Toegarisman, Op. Cit.
} 
author says so because the mechanism of indemnification for the state finance due to corruption is still very complicated and has not been able to reach the seizure of properties suspected to be the proceeds of corruption which are discovered after the convicted of corruption is sentenced.

\section{Re-conceptualization of the}

\section{Indemnification for State Financial}

\section{Loss by Sentencing the Corruptor to}

\section{Compensate his Default}

Therenewaloftheconceptofindemnification for state finances by corruptors is necessary to address the weaknesses of the existing concept of indemnification for state finances by corruptor. Legal framework regarding the indemnification of state finances by the corruptor should be proportionate, effective, efficient, and futuristic. Proportionate means according to its proportion, equal, balanced, impartial. ${ }^{7}$ According to Barda Nawawi Arief, speaking of the effectiveness of laws to combat corruption, there is a problem of "how effective and influential the existing law instruments in preventing and eradicating corruption in Indonesia."

Meanwhile, efficient means right or appropriate to do (produce) something (by not wasting time, effort, and cost). ${ }^{9}$ Futuristic means directional, fixed on the future. Based on the definitions, it can be concluded that for

7 http://kbbi.web.id/proporsional, diakses pada hari Rabu, 6 Juli 2016, pukul 13.17.

8 Barda Nawawi Arief, 2009, Kapita Selekta Hukum Pidana, Bandung: Citra Aditya Bakti, p. 89.

9 http://kbbi.web.id/efisien, accessed on Wednesday, July 6, 2016, at 13.20. the re-conceptualization of indemnification by corruptor to be proportionate, effective, efficient, and futuristic, there should be renewal in the concept of indemnification for state finances that is comparable, successful, right, not wasting time, and can reach the future. ${ }^{10}$

The author also determines that the renewal of the concept of the state financial indemnification by corruptors can be seen in the relationship between the corruptor and the state before the occurrence of the corruption. Civil servants, state officials, individuals, or legal entities that are found guilty of corruption must have engagements with the state before they get the punishment for corruption. The engagement occurred either on the basis of the agreement or the law embodied in an official relationship or cooperation agreement. The engagement results in the rights and obligations for both parties which then become corrupt and the state. The obligations that must be fulfilled to the state can be called an achievement.

Achievement is something that must be met by the debtor in every engagement. Achievement is the content of the engagement. If the debtor fails to meet the achievement as determined in the agreement, he is said in default. ${ }^{11}$ Default means negligence, breach of contract, not fulfilling the obligations under the agreement. ${ }^{12}$ Another opinion also states that default means not fulfilling or fails to perform

${ }^{10} \mathrm{http} / / / \mathrm{kbbi}$.web.id/futuristis, accessed on Wednesday, July 6, 2016, at 13.23.

11 Riduan Syahrani, 2010, Seluk Beluk dan Asas-asas Hukum Perdata, Bandung: Alumni, p. 218.

12 Sudarsono. 2007, Kamus Hukum. Jakarta: Rineka Cipta, p. 578. 
the obligations as specified in the agreement made between the creditor and debtor. ${ }^{13}$

There are several viewpoints on the definition of default (or "wanprestasi" in Indonesian Language) according to experts, among others are:

a. Dr. Wirjono Prodjodikoro, $\mathrm{SH}$

Default is the absence of an accomplishment in the law of contract, meaning something that should be implemented as the content of an agreement. In Indonesian language "achievement is the implementation of the pledge, and default is the absence of implementation of the pledge". ${ }^{14}$

b. Prof. R. Subekti, SH

Default is negligence or omission that may consist of four types:

1) Not doing what he has made in the contract to be done,

2) Doing what he has made in the contract, but not as it should be,

3) Doing what he has made in the contract, but too late,

4) Doing an act which according to the contract cannot be done. ${ }^{15}$

c. H. Mariam Darus Badrulzaman SH

H. Mariam Darus Badrulzaman SH says that if the debtor "because of his fault" does not do what he has made in the contract, the debtor is in default or breaches the contract. The phrase "because of his fault"

13 Marhainis Abdulhay, 2004, Hukum Perdata Materil. Jakarta : Pradnya Paramita, p. 53.

14 Wirjono Prodjodikoro, Asas-asas Hukum Perjanjian, Sumur, Bandung, 1981, p. 17.

15 Subekti, 1991, Hukum Perjanjian, Jakarta: Intermasa, p. 50. is very important, because the debtor does not accomplish what he has agreed in the contract at all not because of his fault. ${ }^{16}$

d. M.Yahya Harahap.

Default can also be intended as the untimely or improper execution of obligation.

Based on the definitions and explanations above, it can be seen that the types of default are as follows:

a. No achievement;

b. Less achievement;

c. Late in meeting achievement;

d. Doing things forbidden in the contract.

Each corruptor must be considered valid to have been in default

Based on the classification of default above, any legal subject who has been proven guilty of corruption must be seen already in default. In case the corruptor is a Civil Servant or official, then in running his official duty, he is bound by the oath of office he aspires. Through the oath of office he declared, he simultaneously has declared the promise to the state, especially to the agency where he works. In return, the state is also bound by a promise to provide the salaries, allowances and facilities to the civil servant and official.

Here is the sound of oath of office:

"By God, I swear / promise. That I am, to be appointed as Civil Servant, faithful and fully obedient to the Pancasila, the Constitution of 1945, the State and the Government;

16 Subekti, Hukum Perjanjian, Intermasa, Jakarta, 1991, p. 59. 
that I will obey all laws and regulations in force and carry out official duties entrusted to me with great devotion, awareness, responsibility;

that I will always uphold the honor of the State, the Government, and the dignity of the Civil Servant, and will always put the interests of the State rather than the interests of my own, a person or group; that I will uphold the secret of something which by its nature or according to the command should I keep secret;

that I will be working honestly, orderly, meticulously, and eagerly for the interests of the state. “

Let's look at the example of the oath of office of Jakarta governor, as one political office:

"By Allah, I swear I'll fulfill my duty as Governor of Jakarta with the best and fairest. Uphold the 1945 Constitution and execute all laws and regulations righteously and dutiful to society, country and nation. "

Based on these oaths, it can be seen that one of the promises of the civil servant and official is that he will abide by all laws and regulations in force. In the case that there is a civil servant or an official who is convicted of corruption, this means that he has significantly violated the legislation. Therefore, he can also be deemed in default because he fails to perform his duties or he fails to perform his achievements as he declared in the oath of office.

In the case that the convicted is individual or private legal entity, he certainly has the basic form of a cooperation agreement with the authorities in doing a specific job using the state budget. As a result, if he is found guilty of corruption, means that he has violated the agreement he made with the government, either with bad intentions or violation of the agreement that later may result in financial losses of the state. On that basis, he can also be considered to have been in default.

\section{Imposition of Sanctions for Corruptor to Indemnify the State Financial Loss}

Non-compliance with the engagement, caused by the negligence of the debtor or in default as a result of circumstances that can risk the debtor, raises some effects. The consequences of default are: ${ }^{17}$

1. The debtor shall pay compensation (Article 1279 BW);

2. The burden of risk shifts toward debtor losses. An obstacle arising to the surface can be accounted to the creditor after the debtor in default, unless there is intent or big negligence (culpa lata) on the part of the creditor or cannot control (overmact).

3 . If the engagement arises from a reciprocal agreement, the creditor can free himself from the obligation to make contra by way of Article 1302 BW or through exceptio non adimpleti contractus to fend off the demands of the debtor to fulfill the engagement.

The loss that can be indemnified is not only the costs that have been spent (Kosten), or the

17 Gr. Van der Burght, 1999, Buku Tentang Perikatan, Bandung: Mandar Maju, p. 131 
loss that falls upon the objects of the indebted (schaden), but also the loss in the form of profits (interessen), the profits obtained if the indebted is not negligent (winstderving). ${ }^{18}$

Compensation is necessary to stop the firstdegree crime, rearrange everything according to the circumstances before the abuse occurs, and restore the condition of the victim of the abuses as what happens if there is no violation of law. ${ }^{19}$

Indemnification is necessary to stop the second-level crime. Punishment alone is not enough for it. It is obvious that punishment tends to reduce the number of offenders, but despite the reduction, the number of offenders can never be considered absent. Examples of various offenses, less well known or not, at least have raised concerns. Everyone who witnesses the abuses worry that he will turn to suffer. If we want the fear is gone, then the violation should always be accompanied by indemnification and penalty. If the violation is only followed by punishment without indemnification, the punishment is not effective. As a result, people are gripped by so many worries. ${ }^{20}$

Every legal subject who is in default must pay indemnification. Indemnification is an attempt to recover losses in which the achievement is subsidiary. This means that if the fulfillment of achievement is no longer possible or no longer

18 Subekti, 2005, Kitab Undang-Undang Hukum Perdata. Cetakan Ketigapuluh enam. Jakarta: Pradnya Paramita, p. 148

19 Jeremy Bentham, 2010, Teori PerundangUndangan, Bandung: Penerbit Nuansa \& NUSAMEDIA

20 Ibid. expected, the indemnification is an alternative that can be chosen by the creditor. Furthermore, associated with the default, Article 1234 of BW states: ${ }^{21}$

"Replacement of costs, loss and interest due to non fulfilment of an engagement will then become an obligatory if the indebted has been declared failure to fulfill the engagement, neglects it, or if something that he should give or make in the dependent time he passes"

From the articles, it can be drawn a conclusion that the definition of indemnification is a sanction that can be charged to debtors who do not meet achievement in an engagement to provide the replacement of costs, losses, and interest. $^{22}$

Cost is all expenses that have been issued by the creditor. Loss is any loss due to the destruction of or damage to goods belonging to the creditors as a result of the debtor's negligence. And interest is all the benefits expected or have been calculated. ${ }^{23}$

Based on the understanding and the provisions of the articles above, it is obvious that that corruptor should also be penalized to pay for the loss. Corruptor is the subject of law. When someone is convicted of corruption, he automatically has also failed to meet achievement in the agreement. If he is a Civil Servant or an official, he has been in default

\footnotetext{
21 Agus Yudha Hernoko, 2010, Hukum Perjanjian Asas Proposionalitas Dalam Kontrak Komersial, Jakarta: Kencana, p. 260-261.

22 Riduan Syahrani, Ibid, p. 222.

23 Ibid.
} 
on the oath of office he ever uttered. If it is the private sector that does civil relations with the government under the agreement, then it is considered in default to the agreement.

Aside from combating the crime, indemnification is also an attempt to prevent or at least minimize the occurrence of corruption in the future. Indemnification is one form of legal liability by criminals. According to the law, liability is a result of the consequences of one's freedom related to ethics or morals in doing an act. ${ }^{24}$ Liability must have a foundation that causes for a legal right to sue others as well as something that give birth another person's legal obligation to provide the accountability. ${ }^{25}$

The above explanation shows that the responsibility of corruptor is a consequence of what he has done. On that basis, the state reserves the right to prosecute corruptor to carry out the obligations relating to the fulfillment of the responsibility for his actions.

The most essential problem is how to calculate the ideal indemnification for the state financial losses and not only limited to the calculation of the amount of the money corrupted. In practice, it needs a professional appraiser in calculating the components of proportionate compensation. In calculating the potential benefits obtained if the proceeds of corruption are used as it should be is not easy. According to the author, in calculating the potential benefits that can be gained should not

24 Soekidjo Notoatmojo, 2010, Etika dan Hukum Kesehatan, Jakarta: Rineka Cipta.

25 Titik Triwulan dan Shinta Febrian, 2010, Perlindungan Hukum Bagi Pasien, Jakarta: Prestasi Pusaka, p. 48. be limited to considering the potential benefits in general in the amount of interest on deposits, which is generally 6-10 percent. Preferably, the estimated potential profit is 50 per cent of the total value of the money corrupted. This value should also be converted in accordance with the time value of the money corrupted. This concept will be able to ensure a deterrent effect rather than the concept of impoverishing the corruptor that has no clear count and immeasurable.

In the previous discussion, it has been described that corruptor can be considered being in default. The author argues that on the basis of the default, the corruptor can also be sentenced to pay indemnification without a civil lawsuit. Default procedure, in principle, is set in the Code of Civil Procedure which is different from the Code of Criminal Procedure. However, on legal grounds that the corruptor has proven guilty, then he can immediately be sentenced to pay indemnification for the breach of contract. Civil liability of the convict should be seen as a continuation of the imposition of criminal penalties against convicted of corruption.

The author sees that there are some advantages in the mechanism of imposition of penalty to the corruptor to pay indemnification due to the default, among others are:

a. The indemnification value, that takes into account the time value of money, the cost of handling the case, and the potential benefits if the money is used properly, will give the effect of a more proportionate loading of 
responsibility because it is much heavier than just the punishment for the value of the proceeds of corruption

b. Time-effective and cost-saving. Therefore, there is no need to wait for the discovery of the properties allegedly earned from the proceeds of corruption and no longer need to hold civil judicial process that requires a lot of costs, such as costs to search for evidence.

c. The properties belonging to the convicted of corruption can be executed immediately as part of the indemnification to the state

To accommodate this re-conceptualization, of course, needs a reform in the laws and regulations in Indonesia related to the procedural law in the case of corruption. Thus, each convicted of corruption can be immediately punished civilly to compensate the state financial losses. Criminal and civil cases, in principle, have a mechanism respectively. But this time, based on the needs of legal, economic, and social realities, the state through legislators can create a new mechanism for imposing criminal penalties against perpetrators of corruption plus civil penalty to pay indemnification.

\section{The failure to pay indemnification shall be defined as the debt for state financial loss}

Corruption Law states that if the assets belonging to the convicted of corruption are not enough to pay the additional penalty as indemnification, then the punishment can be replaced with a maximum confinement of the principal criminal. According to the author, the provision is not able to accommodate the return of state financial losses by the convicted of corruption. Instead, this provision could provide a loophole for the convicted of corruption to conceal the proceeds of corruption as safe as possible until the time he is released or free. And after finishing the punishment, he will begin to use the proceeds of corruption.

After the convicted of corruption is free and begin to use his assets, as the proceeds of corruption, and the government discovers that there are still the proceeds of corruption hidden, then based on the current provisions, the government should pursue a lawsuit in advance. This is certainly a time-consuming and cumbersome. Moreover, the process of finding evidence must go through tough mechanism and the cost is not small. It can be said that the further proofs are wasteful and useless efforts. Meanwhile, the aspect of the indemnification of state finance has been settled since the beginning by giving punitive damages for the tort to the state. But then, if the convicted fails to pay indemnification for the corruption he committed, the total value of indemnification which cannot be paid should be determined through a court ruling as a debt on state financial loss.

With the establishment of the liabilities to the state losses for the corruptors who fail to pay the indemnification, the authors look at some advantages, such as:

a. If the corruptor still has assets after he runs his sentence, then the assets can be executed directly as part of the settlement of debt to 
the state by considering the time value of money. With this mechanism, there is no need to hold civil lawsuit because, based on the concept that has been previously described, the convicted of corruption by law has the obligation to indemnify the state, without considering whether such property is the proceeds of corruption or not. Thus, the desire to indemnify the state financial losses proportionately and effectively can be maintained.

b. Debt can be a responsibility, both moral and economic inherent throughout the life of the corruptors. This means that in lifelong the convicted of corruption still has debts to the state as long as the debt has not been repaid. Even in later days when he is free and then has an asset for his efforts, he must still pay the debt to the state.

c. Debt can also be forwarded to the heir if the legal subject dies, as long as he does not refuse his rights as an heir. This system can accommodate the possibility that the proceeds of corruption are transferred to and used by the heir.

If this concept is applied, it will raise a deterrent effect because the corruption will not only assume the responsibility for his actions during his life, but also will leave that responsibility to his heir. Thus, one would think many times before committing corruption. In the concept of life and law, the author sees this concept is more severe but measurable than the concept of impoverishment of corruptor.

Furthermore, the author sees that the effort of default claims are more appropriate in a situation where the heir refuses his right as the heir. This can happen because the heir debts are larger than the inherited wealth. By rejecting the right of as the heir, he has refused all assets and liabilities of the testator. Thus, the heir's assets can be immediately executed as part of payment of compensation to the state. If in the future the heir who refuses the right as the heir is known to have other property suspected to be the proceeds of corruption, it requires a civil suit to the heir. In this case, the law enforcer must enter a civil suit because the heir has released disinherited, meaning that he has disposed of all their rights to the legacy left by the testator, either in the form of assets or responsibilities, including debts to the state. In this condition, a civil action is necessary for the proper fulfillment of the principle of fairness.

\section{E. CLOSING}

\section{Conclusion}

Based on the explanation above, it can be concluded that the re-conceptualization of the indemnification for the state financial loss on the basis of proportionality, effectiveness, efficiency, and future reach is as follows:

a. Declaring the default for each person who has been found guilty of corruption because he has failed to fulfill not only his oath of office, but also his agreement with the government. Hence, corruptor, who is also regarded and declared in default, shall be sentenced to pay indemnification for the breach of contract to the state. The imposition of indemnification is determined not only by the amount of the state financial loss caused by corruption, but also taking into account the time value of 
money.

b. If the corruptor fails to indemnify the financial loss to the state, then the difference of indemnification unpaid should be considered as a debt to the state which can be recovered in the future.

\section{Implication}

a. With the enactment of the concept of indemnification for state finances by corruptors on the basis of proportionality, effectiveness, efficiency, and future reach as described in this article, there will be some implications as follows:

1) The determination made by the judge on the amount of indemnification paid to the state by the corruptors will be proportionate because it does not only take into account the amount of financial losses occurring as a result of corruption, but also the time value of money, the cost of handling the case, and the potential benefits if the state money is used properly.

2) With the enactment of financial indemnification imposed to the corruptor, there will be an increase in the effectiveness and cost-saving time, because there is no need to hold civil legal proceedings in the future that requires a lot of costs, such as costs to search for evidence.

3) The assets belonged to the convicted of corruption can be immediately executed as part of the indemnification to the state.

b. By setting the difference in indemnification, the amount that cannot be paid by the corruptor, as a debt to the state which can be charged in the future, then the implications that will occur are as follows:

1) If any properties belonged to the convicted of corruption are found in the future, then the properties can be executed directly as part of a debt repayment to the state.

2) It can be a moral and economic responsibility for life for the corruptors, as long as the debt is not repaid.

3) The debt can also be forwarded to the heir if the legal subject died, as long as the heir does not reject his rights as an heir. This system can accommodate the possibility that the proceeds of corruption are transferred to and / or used by the heir.

\section{Limitation}

The limitation in the effort to implement this concept is on the lack of the readiness of the legal framework for the implementation of this concept. Law on corruption is still limited to the establishment of the amount of financial indemnification for the money corrupted. In addition, default is in the realm of civil law, while corruption is in the realm of criminal law. Both have different procedural law. This article itself is basically aims to reorganize and renew the problems arising from the existing situation and the limitations, including limitations on the procedural law today.

\section{Suggestion}

Based on the conclusions, implications, and limitations, it is suggested that the Parliament and Government revise the Law on Corruption by inserting a clause which states that a corruptor basically has hurt the government. In addition, the Parliament and Government 
should include provisions on the calculation of the indemnification for state financial loss based on the time value of money, cost, and potential benefits that might be gained if the state money is used properly. The provision on the substitution of financial indemnification with the confinement should be removed and the indemnification for the state financial loss should be designated as a debt to the state.

\section{REFERENCES}

\section{A. Books}

Abdulhay, Marhainis. 2004. Hukum Perdata Materil. Jakarta: Pradnya Paramita.

Agus Yudha Hernoko. 2010. Hukum Perjanjian Asas Proposionalitas Dalam Kontrak Komersial. Jakarta: Kencana.

Arief, Barda Nawawi. 2009. Kapita Selekta Hukum Pidana. Bandung: Citra Aditya Bakti.

Bentham, Jeremy. 2010. Teori PerundangUndangan. Bandung: Penerbit Nuansa \& Nusamedia.

Burght, Gr. Van der. 1999. Buku Tentang Perikatan. Bandung: Mandar Maju.

Notoatmojo, Soekidjo. 2010. Etika dan Hukum Kesehatan. Jakarta: Rineka Cipta.

Prodjodikoro, Wirjono. 1981. Asas-asas Hukum Perjanjian. Bandung:Sumur.

Subekti, 1991, Hukum Perjanjian, Jakarta: Intermasa.

Subekti. 2005. Kitab Undang-Undang Hukum Perdata. Cetakan Ketigapuluh enam. Jakarta: Pradnya Paramita.
Sudarsono.2007. Kamus Hukum. Jakarta: Rineka Cipta.

Syahrani, Riduan. 2010. Seluk Beluk dan Asasasas Hukum Perdata. Bandung: Alumni.

Triwulan, Titik dan Shinta Febrian. 2010. Perlindungan Hukum Bagi Pasien. Jakarta: Prestasi Pusaka

Toegarisman, M. Adi. 2016. Pemberantasan Korupsi Dalam Paradigma Efisiensi. Jakarta: Kompas.

\section{B. Legislations}

Code of Civil Law (hereinafter referred as Kitab Undang-Undang Hukum Perdata)

Law No. 31 of 1999 Jo Law No. 20 of 2001 on Corruption Eradication

\section{Internet}

http://kbbi.web.id/proporsional

http://kbbi.web.id/efisien

http://kbbi.web.id/futuristis

hukumonline.com 